\title{
THE CHOLINE-CONTAINING PHOSPHOLIPIDS OF SERUM ${ }^{2}$
}

\author{
By MARGARET J. ALBRINK 2 \\ (From the Department of Internal Medicine of the Yale University School of Medicine, and the \\ Medical Service of the New Haven Hospital, New Haven, Conn.)
}

(Received for publication July 14, 1949)

In view of the well-established role of choline as a lipotropic factor (1-5), it seemed of interest to determine whether a relative or absolute deficiency of lipotropic substances was a factor contributing to human liver disease. If this were the case it might be interpreted as an abnormality in the choline-containing fraction of the serum phospholipids. Aside from the possible etiological significance of choline in liver disease, a change in the serum phospholipids might be expected as a result of disturbed liver function, since isotope studies have shown that the liver is the chief site of incorporation of phosphorus into the phospholipids destined for the serum (6). For this reason it was decided to add the determination of lipid choline to the determinations of free and total cholesterol, fatty acids and lipid phosphorus usually carried out in this laboratory as part of the study of patients with liver disease. To have a basis for comparison the study was extended to normal individuals and to patients with other diseases.

\section{METHODS}

All determinations were done on serum drawn in the fasting state. Lipid phosphorus and choline were determined on chloroform-methanol extracts which were prepared and washed free of non-lipid extractives by the method of Folch (7). Phosphorus values of this extract agreed well with those of simultaneously prepared alcohol-ether extracts. The phosphorus was determined by a modification of the method of Fiske and Subbarow (8), using the smaller quantities of aminonaphtholsulfonic acid suggested by Sperry (9). Choline was determined by the micro method of Folch (10). In this method the lipids are hydrolyzed by half-saturated barium hydroxide and the choline thus liberated is precipitated by phosphotungstic acid as choline phosphotungstate. After suitable washing the precipitate is decomposed by the addition of sodium hydroxide in a quantitative volumetric reaction.

1 This investigation was supported (in part) by a research grant from the Division of Research Grants and Fellowships of the National Institutes of Health, U. S. Public Health Service.

2 National Institutes of Health Postdoctorate Research Fellow.
The method was checked by carrying out determinations on choline chloride which had been recrystallized from absolute alcohol, and on purified lecithin (gift from Dr. Mary Pangborn). Optimum recoveries of choline chloride were obtained when aliquots of 60 to 150 gamma were used. Recoveries were then 97 per cent of the theoretical, \pm 1.5 per cent. The recovery of choline from purified lecithin (beef heart and egg) was of the same order of magnitude. Choline added to serum lipid extracts as lecithin or choline chloride was completely recovered.

\section{RESULTS}

All figures represent averages of duplicate determinations. The results are expressed in terms of millimoles of lipid phosphorus and millimoles of

TABLE I

Serum phospholipids of normal persons

\begin{tabular}{|c|c|c|c|}
\hline Subject & $\begin{array}{c}\text { Lipid } \\
\text { phosphorus }\end{array}$ & $\begin{array}{l}\text { Lipid } \\
\text { choline }\end{array}$ & $\frac{\text { Moles choline }}{\text { Moles phosphorus }}$ \\
\hline $\begin{array}{r}2 \\
\\
3 \\
4 \\
5 \\
6 \\
7 \\
8 \\
9 \\
10 \\
11 \\
12 \\
13 \\
14 \\
15 \\
16 \\
17 \\
18 \\
19 \\
20 \\
21 \\
22 \\
23\end{array}$ & $\begin{array}{c}m M \text { per liter } \\
3.06 \\
3.29 \\
3.29 \\
3.19 \\
3.29 \\
2.68 \\
3.12 \\
2.84 \\
2.81 \\
2.70 \\
2.97 \\
2.55 \\
2.74 \\
2.80 \\
3.26 \\
2.87 \\
2.48 \\
2.42 \\
2.58 \\
3.78 \\
2.84 \\
2.70 \\
2.64 \\
3.10 \\
2.26 \\
2.51 \\
2.80 \\
2.48 \\
2.68 \\
2.16\end{array}$ & $\begin{array}{c}m M \text { per liter } \\
2.29 \\
2.40 \\
2.40 \\
2.34 \\
2.51 \\
2.05 \\
2.36 \\
2.04 \\
2.16 \\
2.07 \\
2.17 \\
1.98 \\
2.13 \\
2.02 \\
2.35 \\
2.10 \\
1.84 \\
1.89 \\
1.96 \\
2.71 \\
2.04 \\
1.90 \\
1.86 \\
2.24 \\
1.64 \\
1.97 \\
2.04 \\
1.87 \\
1.97 \\
1.72\end{array}$ & $\begin{array}{l}0.75 \\
0.73 \\
0.73 \\
0.73 \\
0.76 \\
0.76 \\
0.76 \\
0.72 \\
0.77 \\
0.76 \\
0.73 \\
0.78 \\
0.78 \\
0.72 \\
0.72 \\
0.73 \\
0.74 \\
0.78 \\
0.76 \\
0.72 \\
0.72 \\
0.70 \\
0.70 \\
0.72 \\
0.73 \\
0.78 \\
0.73 \\
0.75 \\
0.74 \\
0.80\end{array}$ \\
\hline Average & 2.83 & 2.10 & 7.43 \\
\hline
\end{tabular}


lipid choline per liter of serum. The phosphorus of phosphorus the molar values for lipid phosand choline values may be converted from milli- phorus represent the total phospholipid in moles. moles to milligrams per liter by multiplying by Similarly, since the choline-containing phosphotheir molecular weights, $\cdot 31$ and 121 , respectively. lipids, lecithin and sphingomyelin, each contain Since each mole of phospholipid contains one mole one mole of choline, the choline values are equiva-

TABLE II

Serum lipids of patients with liver disease

\begin{tabular}{|c|c|c|c|c|c|c|c|c|}
\hline \multirow{2}{*}{ Case number } & \multirow{2}{*}{ Date } & \multicolumn{3}{|c|}{ Cholesterol } & \multirow{2}{*}{$\begin{array}{l}\text { Fatty } \\
\text { acids }\end{array}$} & \multirow{2}{*}{$\begin{array}{l}\text { Lipid } \\
\text { phosphorus }\end{array}$} & \multirow{2}{*}{$\begin{array}{c}\text { Lipid } \\
\text { choline }\end{array}$} & \multirow{2}{*}{$\frac{\text { Moles choline }}{\text { Moles phosphorus }}$} \\
\hline & & Total & Free & Per cent free & & & & \\
\hline & & $\underset{\text { per cent }}{\operatorname{mgm} .}$ & $\underset{\text { per cent }}{\text { mgm. }}$ & & $\begin{array}{l}\text { m. eq. per } \\
\text { liter }\end{array}$ & $\begin{array}{c}m M \text { per } \\
\text { liter }\end{array}$ & $\underset{\text { liter }}{m M}$ per & \\
\hline
\end{tabular}

Cirrhosis

\begin{tabular}{|c|c|c|c|c|c|c|c|c|}
\hline $\begin{array}{r}\text { A15392 } \\
\text { B3677 } \\
8870 \\
45365 \\
\text { B96343 }\end{array}$ & $\begin{array}{r}3-21-48 \\
6-4-48 \\
9-29-48 \\
10-8-48 \\
6-9-48\end{array}$ & $\begin{array}{l}123 \\
197 \\
267 \\
236 \\
121\end{array}$ & $\begin{array}{l}39 \\
66 \\
78 \\
72 \\
36\end{array}$ & $\begin{array}{l}32 \\
33 \\
30 \\
30 \\
30\end{array}$ & $\begin{array}{r}8.3 \\
12.2 \\
20.7 \\
15.4 \\
7.9\end{array}$ & $\begin{array}{l}2.29 \\
3.29 \\
3.84 \\
3.48 \\
2.03\end{array}$ & $\begin{array}{l}1.66 \\
2.60 \\
2.86 \\
2.64 \\
1.57\end{array}$ & $\begin{array}{l}0.73 \\
0.79 \\
0.74 \\
0.76 \\
0.77\end{array}$ \\
\hline \multicolumn{9}{|c|}{ Cirrhosis with Ascites } \\
\hline $\begin{array}{r}\text { A10534 } \\
\text { B61846 } \\
\text { B61846 } \\
\text { C4947 } \\
\text { B79312 } \\
\text { C13065 } \\
\text { C8329 }\end{array}$ & $\begin{array}{l}6-1-48 \\
6-14-48 \\
7-9-48 \\
7-7-48 \\
3-5-49 \\
7-7-48 \\
3-16-48\end{array}$ & $\begin{array}{l}107 \\
170 \\
\\
126 \\
179 \\
126 \\
100\end{array}$ & $\begin{array}{l}32 \\
68 \\
\\
38 \\
60 \\
56 \\
93\end{array}$ & $\begin{array}{l}30 \\
40 \\
\\
30 \\
34 \\
44 \\
93\end{array}$ & $\begin{array}{r}7.8 \\
10.4 \\
\\
9.2 \\
13.0 \\
8.9 \\
14.7\end{array}$ & $\begin{array}{l}1.94 \\
2.58 \\
1.62 \\
2.58 \\
2.71 \\
2.16 \\
3.03\end{array}$ & $\begin{array}{l}1.53 \\
2.11 \\
1.28 \\
1.78 \\
2.17 \\
1.59 \\
2.32\end{array}$ & $\begin{array}{l}0.79 \\
0.82 \\
0.79 \\
0.69 \\
0.80 \\
0.74 \\
0.77\end{array}$ \\
\hline \multicolumn{9}{|c|}{ Biliary Cirrhosis } \\
\hline B61472 & $5-4-48$ & 199 & 88 & 44 & 11.8 & 3.04 & 2.10 & 0.69 \\
\hline \multicolumn{9}{|c|}{ Infectious Hepatitis } \\
\hline $\begin{array}{r}C 13800 \\
C 13800 \\
C 13800 \\
C 13800 \\
C 15957 \\
\text { A27118 } \\
\text { C6694 } \\
\text { C6828 } \\
\text { C23035 }\end{array}$ & $\begin{array}{l}7-14-48 \\
7-22-48 \\
7-26-48 \\
9-3-48 \\
9-12-48 \\
9-14-48 \\
7-3-48 \\
4-23-48 \\
3-7-49\end{array}$ & $\begin{array}{l}159 \\
242 \\
230 \\
242 \\
159 \\
253 \\
208 \\
220 \\
195\end{array}$ & $\begin{array}{r}113 \\
144 \\
106 \\
67 \\
56 \\
167 \\
54 \\
99 \\
156\end{array}$ & $\begin{array}{l}71 \\
59 \\
46 \\
27 \\
35 \\
66 \\
26 \\
45 \\
80\end{array}$ & $\begin{array}{l}18.5 \\
21.1 \\
16.3 \\
12.3 \\
13.5 \\
27.1 \\
15.4 \\
16.5 \\
24.8\end{array}$ & $\begin{array}{l}4.48 \\
5.58 \\
3.97 \\
3.26 \\
2.80 \\
6.14 \\
2.84 \\
3.77 \\
6.26\end{array}$ & $\begin{array}{l}3.26 \\
3.95 \\
2.88 \\
2.45 \\
2.08 \\
4.60 \\
2.04 \\
2.70 \\
4.34\end{array}$ & $\begin{array}{l}0.73 \\
0.71 \\
0.73 \\
0.75 \\
0.74 \\
0.75 \\
0.72 \\
0.72 \\
0.69\end{array}$ \\
\hline \multicolumn{9}{|c|}{ Biliary Obstruction } \\
\hline $\begin{array}{r}\text { C8553 } \\
\text { C1566 } \\
\text { C17071 } \\
\text { C12307 } \\
\text { A61886 } \\
\text { A69597 }\end{array}$ & $\begin{array}{r}3-17-48 \\
9-29-47 \\
10-9-48 \\
6-23-48 \\
7-16-48 \\
2-28-49\end{array}$ & $\begin{array}{l}342 \\
261 \\
131 \\
189 \\
288 \\
155\end{array}$ & $\begin{array}{r}271 \\
182 \\
55 \\
101 \\
151 \\
81\end{array}$ & $\begin{array}{l}79 \\
70 \\
42 \\
53 \\
52 \\
52\end{array}$ & $\begin{array}{r}24.6 \\
24.9 \\
9.6 \\
11.4 \\
28.9 \\
16.8\end{array}$ & $\begin{array}{l}8.32 \\
5.84 \\
2.42 \\
3.55 \\
5.70 \\
3.45\end{array}$ & $\begin{array}{l}6.50 \\
4.74 \\
1.83 \\
2.60 \\
4.24 \\
2.55\end{array}$ & $\begin{array}{l}0.78 \\
0.81 \\
0.76 \\
0.73 \\
0.74 \\
0.74\end{array}$ \\
\hline \multicolumn{9}{|c|}{ Steatorrhea } \\
\hline $\begin{array}{l}\text { B16664 } \\
\text { B99806 }\end{array}$ & $\begin{array}{r}12-1-48 \\
5-21-48\end{array}$ & $\begin{array}{r}145 \\
83\end{array}$ & $\begin{array}{l}47 \\
32\end{array}$ & $\begin{array}{l}32 \\
39\end{array}$ & $\begin{array}{r}11.8 \\
5.8\end{array}$ & $\begin{array}{l}2.58 \\
1.77\end{array}$ & $\begin{array}{l}1.96 \\
1.27\end{array}$ & $\begin{array}{l}0.76 \\
0.72\end{array}$ \\
\hline
\end{tabular}


TABLE III

Serum lipids in patients with miscellaneous diseases

\begin{tabular}{|c|c|c|c|c|c|c|c|c|}
\hline \multirow{2}{*}{ Case number } & \multirow{2}{*}{ Date } & \multicolumn{3}{|c|}{ Cholesterol } & \multirow{2}{*}{$\begin{array}{l}\text { Fatty } \\
\text { acids }\end{array}$} & \multirow{2}{*}{$\begin{array}{c}\text { Lipid } \\
\text { phosphorus }\end{array}$} & \multirow{2}{*}{$\begin{array}{l}\text { Lipid } \\
\text { choline }\end{array}$} & \multirow{2}{*}{$\frac{\text { Moles choline }}{\text { Moles phosphorus }}$} \\
\hline & & Total & Free & Per cent free & & & & \\
\hline & & $\underset{\text { per cent }}{\operatorname{mgm} .}$ & $\underset{\text { per cent }}{\operatorname{mgm}}$ & & $\begin{array}{l}\text { m. eq. per } \\
\text { liter }\end{array}$ & $\begin{array}{c}m M \text { per } \\
\text { liter }\end{array}$ & $\begin{array}{c}\text { mM per } \\
\text { liter }\end{array}$ & \\
\hline \multicolumn{9}{|c|}{ Hyperthyroidism } \\
\hline $\begin{array}{l}\text { B90726 } \\
\text { B73533 } \\
\text { C11587 }\end{array}$ & $\begin{array}{l}7-9-48 \\
6-7-48 \\
5-22-48\end{array}$ & $\begin{array}{l}146 \\
120 \\
103\end{array}$ & $\begin{array}{l}41 \\
36 \\
43\end{array}$ & $\begin{array}{l}28 \\
30 \\
42\end{array}$ & $\begin{array}{l}9.9 \\
7.9\end{array}$ & $\begin{array}{l}2.26 \\
2.10 \\
1.71\end{array}$ & $\begin{array}{l}1.73 \\
1.72 \\
1.24\end{array}$ & $\begin{array}{l}0.77 \\
0.82 \\
0.72\end{array}$ \\
\hline \multicolumn{9}{|c|}{ Hemolytic Anemia } \\
\hline C17492 & $10-18-48$ & 61 & 20 & 32 & & 1.29 & 1.04 & 0.80 \\
\hline \multicolumn{9}{|c|}{ Nephrosis } \\
\hline $\begin{array}{l}\text { B74160 } \\
\text { B94483 }\end{array}$ & $\begin{array}{r}12-19-47 \\
5-21-48\end{array}$ & 474 & 139 & 29 & 35.4 & $\begin{array}{l}6.32 \\
3.55\end{array}$ & $\begin{array}{l}4.68 \\
2.44\end{array}$ & $\begin{array}{l}0.74 \\
0.69\end{array}$ \\
\hline \multicolumn{9}{|c|}{ Toxemia of Pregnancy } \\
\hline & $8-27-48$ & 329 & 94 & 29 & 24.6 & 4.55 & 3.21 & 0.71 \\
\hline \multicolumn{9}{|c|}{ Diabetes, Recent Ketosis } \\
\hline $\begin{array}{r}\text { A66992 } \\
23406\end{array}$ & $\begin{array}{r}9-29-48 \\
10-22-48\end{array}$ & 295 & 87 & 29 & 21.1 & $\begin{array}{l}4.84 \\
2.90\end{array}$ & $\begin{array}{l}3.60 \\
2.25\end{array}$ & $\begin{array}{l}0.74 \\
0.78\end{array}$ \\
\hline \multicolumn{9}{|c|}{ Diabetes, Terminal Renal Failure } \\
\hline 29244 & $9-22-48$ & & & & & 2.74 & 1.92 & 0.70 \\
\hline \multicolumn{9}{|c|}{ Xanthomatosis } \\
\hline $\begin{array}{l}\text { B43143 } \\
\text { C18412 }\end{array}$ & $\begin{array}{r}9-24-48 \\
11-8-48\end{array}$ & $\begin{array}{l}341 \\
319\end{array}$ & $\begin{array}{r}123 \\
96\end{array}$ & $\begin{array}{l}37 \\
30\end{array}$ & $\begin{array}{l}21.9 \\
33.3\end{array}$ & $\begin{array}{l}4.84 \\
4.84\end{array}$ & $\begin{array}{l}3.53 \\
3.40\end{array}$ & $\begin{array}{l}0.73 \\
0.70\end{array}$ \\
\hline
\end{tabular}

lent to the total choline-containing phospholipids. The molar ratio of choline to phosphorus which has been calculated in each case indicates the ratio of choline-containing to total phospholipids.

Thirty determinations of lipid phosphorus and choline were carried out on the serum of 23 normal individuals of both sexes, most of whom were young adults, two of whom were elderly individuals. The results are given in Table I. The lipid phosphorus varied from 2.16 to 3.78 with an average of 2.83 millimoles per liter. The ratio of moles choline to moles phosphorus varied from 0.70 to 0.80 . The constancy of the ratio in one individual with time is shown by the five determinations in
Subject 1 and the two determinations in Subject 2. The error in duplicate determinations was somewhat greater for serum than for pure choline but did not exceed 5 per cent when aliquots containing optimum quantities of choline were used.

In Table II are listed the patients with various diseases of the liver and biliary system. The values for the cholesterol fractions and fatty acids, which were measured simultaneously on alcoholether extracts of the serum by methods previously described (11), are included. They will be discussed more fully in a future communication. The patients with cirrhosis are divided into three cate- 
gories: cirrhosis with and without ascites; and biliary cirrhosis and toxic nodular cirrhosis. The changes in the total lipids and in the cholesterol fractions correspond well with changes usually found in these diseases (12). The phospholipids were lowest in the patients with ascites. However even when the total lipid phosphorus was outside the normal range of 2.16 to 3.78 millimoles per liter the ratio of choline to phosphorus was the same as that found in normal serum.

The serum lipids of six patients in various stages of infectious hepatitis were analyzed (Table II). In the first patient there were serial determinations throughout the course of the disease. The expected increase in the per cent of cholesterol present in the free form occurred during the acute stage in each case (Patient C6694 was convalescent). Although the total lipid phosphorus was elevated in three patients, the ratio of choline to phosphorus was within the normal range in all cases.

Six patients with biliary obstruction (Table II) showed a constancy of the choline to phosphorus ratio in spite of marked changes in the proportions of the other fractions. Two patients with steatorrhea, the first on a basis of carcinoma of the pancreas, the second probably on a basis of primary small intestinal disease, both had lipid choline levels bearing a normal relationship to the lipid phosphorus.

In Table III are listed four patients with diseases often associated with low lipids, i.e., hyperthyroidism and hemolytic anemia; and seven patients with diseases usually associated with high lipids, that is, diabetes, nephrosis, xanthomatosis, and in addition, a patient with toxemia of pregnancy who displayed high serum lipids. Again the percentage of choline-containing phospholipids remained essentially unchanged in the presence of marked changes in the total lipids.

\section{DISCUSSION}

The finding in normal human serum lipids of a ratio of choline to phosphorus of 0.70 to 0.80 warrants comparison with other reports in the literature. The early works of Kirk (13) and Thannhauser (14), who used variations of the periodide method, showed average lipid choline to phosphorus ratios in human plasma of 0.53 and 0.58 , respectively. Using variations of the same technique Erickson et al. (15) found average ra- tios of 0.71 , and Artom (16) of 0.80 . The latter was able to confirm the plausibility of his choline values by the finding in one determination on human serum that the sum of ethanolamine and serine-containing phospholipids (cephalins) was very close to the total of non-choline-containing phospholipids (17). Using various modifications of the reineckate method originally described by Beattie (18), Brante (19), and Marenzi et al. (20) each found an average value of 0.78 , in good agreement with the above. Blix (21) found an average value of 0.73 , calculating the cephalin, lecithin and sphingomyelin values from determined values for lipid phosphorus, glycerine, and fatty acids.

Contrary to these findings, Taurog et al. (22) reported that 95 to 100 per cent of the phospholipids of normal human serum are of the cholinecontaining variety. Hack (23) confirmed this, finding choline to lipid phosphorus ratios averaging 0.95 , individual variations being largely limited to the narrow range of 0.90 to 1.00 . Sinclair (24), taking meticulous precautions to obtain the phospholipids in a pure form and uncontaminated by non-lipid impurities, found values ranging from 0.92 to 0.94 in four human plasmas. While these higher values probably represent a more complete recovery of choline from the phospholipid, all the workers reporting the latter high values of choline to phosphorus have used variations of the reineckate method which shares the disadvantage common to all choline methods of non-specificity. The possibility that these values are too high because of the presence of a non-choline base in phospholipids which reacts with reineckate has not been ruled out.

Nevertheless, the average value of 0.75 for the ratio of choline-containing to total phospholipids in normal serum reported here, when considered in the light of the more recent works may represent incomplete recovery of choline. The method in Folch's hands, when applied in a few cases to human serum, has yielded values about 10 per cent higher for choline, though some of his determinations have fallen within the range reported here (25).

In spite of the lack of agreement concerning the normal concentration of choline a comparison of the levels found in normal and pathological sera by a single method seemed justified. The results obtained indicate that the larger part of the serum 
phospholipids are the choline-containing lecithin and sphingomyelin, and that the ratio of cholinecontaining to total phospholipids is constant in normal individuals, and patients with or without liver disease regardless of the concentrations of the total phospholipids or of the other lipid fractions. On the basis of the determinations made it is not possible to state whether or not the relationship of the two choline-containing phospholipids, lecithin and sphingomyelin, remains constant.

The finding of normal choline to phosphorus ratios in these cases is not necessarily at variance with the reports in the literature. The experimental evidence forthcoming on the subject is limited chiefly to a study of the liver and serum phospholipids of animals with fatty livers produced either by dietary deficiency or by pancreatectomy. In the first category Artom (4) found a marked decrease in the liver phospholipids of adult rats in whom fatty livers had developed as a result of diet deficient in choline and probably in other substances. There was also a slight decrease in the ratio of choline-containing to non-choline-containing phospholipids, but this was small and not very convincing. Under certain special circumstances, that is, in weanling rats who had been on the deficient diet for seven to 15 days, there was a distinct drop in the ratio of choline-containing to total phospholipids from about 0.60 to 0.50 , and this change could be prevented by adding choline to the diet.

In studying the fatty livers which developed in depancreatized dogs maintained on insulin, Chaikoff (26) found a fall in the serum total phospholipids of these animals, and later (5) demonstrated a similar drop in the serum lipid choline. However, in this last study it was assumed that, as in normal dogs (22), all of the plasma phospholipids were of the choline-containing variety. The ratio of choline-containing to non-choline-containing phospholipids was not actually measured.

Thus, while a decrease in the percentage of the phospholipids of the liver which contain choline has been produced experimentally, it is transitory and difficult to demonstrate, and observations on coincident changes in the serum have concerned only the total phospholipids. Of the patients reported in this paper it is doubtful that any had acute fatty livers of the sort associated with a decrease in the percentage of choline-containing phospholipids of the liver. Liver biopsies on five of the patients with cirrhosis showed the absence of fat in three, and $3+$ or $4+$ fat in two (C4947 and $\mathrm{B} 79312$, Table II). The choline ratios of these two were not significantly different from the others. Most of the cirrhotics had long-standing liver disease which may have had its origins in dietary fatty liver, but which had gone on to fibrosis. Stueck et al. (27) fractionated the liver phospholipids into choline-containing and noncholine-containing in four patients with cirrhosis. In three the ratio was normal, and in one the lecithin fraction was relatively high, but in none was it lower than normal. In infectious hepatitis fatty livers are not usually found, although lipotropic agents may be of some help. Even if the formation of choline-containing phospholipids by the liver was depressed a change in the ratio of cholinecontaining to total phospholipids would be more difficult to demonstrate in serum than in the liver, because of the relatively smaller amounts of noncholine-containing phospholipids present in the former. A fall in the plasma lipid choline would be reflected by a fall in the total phospholipids rather than in the ratio of choline to phosphorus. Such a fall in the total phospholipids of both serum and liver is a well-known consequence of liver damage, and is much more marked than the changes reported by Artom in the fractions. Finally it should be added that according to isotope studies the turnover of the choline-containing phospholipids of plasma and liver may be altered considerably without any demonstrable change in the actual concentration of choline (28).

The results of the present study indicate that any abnormality in phospholipid metabolism will manifest itself as a change in the total lipid phosphorus rather than by changes within the phospholipid fractions.

\section{SUMMARY}

The ratio of choline-containing to total phospholipids was calculated from the levels of lipid choline and lipid phosphorus in the serum of 23 normal individuals, in 27 patients with diseases of the liver or biliary tract including cirrhosis, infectious hepatitis and biliary obstruction, and in 12 patients with other diseases. By the methods used 70 to 80 per cent of the serum phospholipids of normal individuals was found to be of the choline- 
containing variety. Values in the same range were found in the patients with hepatic and biliary tract disease and in the patients with miscellaneous diseases, even when there were marked alterations in the other lipid fractions. The significance of normal phospholipid fractions in patients with liver disease is discussed.

\section{ACKNOWLEDGMENTS}

To Dr. John P. Peters and Dr. Evelyn B. Man grateful acknowledgment is given for advice and encouragement, and to Dr. J. Folch for generously permitting the use of his choline method.

\section{BIBLIOGRAPHY}

1. Best, C. H., and Hershey, J. M., Further observations on the effects of some component of crude lecithin on depancreatized animals. J. Physiol., 1932, 75, 49.

2. Best, C. H., and Huntsman, M. E., The effects of the components of lecithin upon deposition of fat in the liver. J. Physiol., 1932, 75, 405.

3. Best, C. H., Channon, H. J., and Ridout, J. H., Choline and the dietary production of fatty livers. J. Physiol., 1934, 81, 409.

4. Artom, C., and Fishman, W. H., The relation of the diet to the composition of tissue phospholipids. III. Effects of supplemented experimental diets on tissue phospholipids in rats of two age groups. J. Biol. Chem., 1943, 148, 423.

5. Chaikoff, I. L., Entenman, S., and Montgomery, M. L., The mechanism of the antifatty liver factor of the pancreas. I. Its relation to plasma choline. J. Biol. Chem., 1945, 160, 387.

6. Fishler, M. C., Entenman, C., Montgomery, M. L., and Chaikoff, I. L., The formation of phospholipid by the hepatectomized dog as measured with radioactive phosphorus; site of formation of plasma phospholipids. J. Biol. Chem., 1943, 150, 47.

7. Folch, J., and Ascoli, I., Method for the preparation of total pure lipid extracts from blood plasma. To be published.

8. Fiske, C. H., and Subbarow, Y., The colorimetric determination of phosphorus. J. Biol. Chem., 1925, 66, 375.

9. Sperry, W. M., Electrophotometric microdetermination of phosphorus in lipide extracts. Ind. \& Eng. Chem., 1942, 14, 88.

10. Folch, J., and Fitzsimmons, J., Choline estimation in lipids. To be published.

11. Peters, J. P., and Man, E. B., The interrelations of serum lipids in normal persons. J. Clin. Invest., 1943, 22, 707.

12. Man, E. B., Kartin, B. L., Durlacher, S. H., and Peters, J. P., The lipids of serum and liver in patients with hepatic diseases. J. Clin. Invest., 1945, 24, 623.

13. Kirk, E., A micromethod for approximate estimation of lecithin, cephalin, ether-insoluble phosphatide, and cerebrosides in plasma, red blood cells, and tissue. J. Biol. Chem., 1938, 123, 623.

14. Thannhauser, S. J., Benotti, J., and Reinstein, H., Studies on animal lipids. XIV. The determination of lecithin, cephalin and sphingomyelin in body fluids and tissues; with analyses of normal human sera. J. Biol. Chem., 1939, 129, 709.

15. Erickson, B. N., Avrin, I., Teague, D. M., and Williams, H. H., Micromethods for determination of sphingomyelin and choline. Applications for the estimation of the phospholipid partition (sphingomyelin, lecithin, and cephalin) in blood and tissues. J. Biol. Chem., 1940, 135, 671.

16. Artom, C., Cephalins, choline-containing phospholipids, and total phospholipids in normal human plasma. J. Biol. Chem., 1941, 139, 65.

17. Artom, C., Some data on the distribution of individual phospholipids in rat tissues and in human plasma. J. Biol. Chem., 1945, 157, 595.

18. Beattie, F. J. R., A colorimetric method for the determination of choline and acetylcholine in small amounts. Biochem. J., 1936, 30, 1554.

19. Brante, G., Cholin- und Colaminphosphatide des Blutserums bei alimentärer Lipämie. Biochem. Ztschr., 1940, 305, 136.

20. Marenzi, A. D., and Cardini, C. E., The colorimetric determination of choline. J. Biol. Chem., 1943, 147, 363.

21. Blix, G., Zur Chemie der Blutserumphosphatide. Biochem. Ztschr., 1940, 305, 129.

22. Taurog, A., Entenman, E., and Chaikoff, I. L., The choline-containing and non-choline-containing phospholipids of plasma. J. Biol. Chem., 1944, 156, 385.

23. Hack, M. H., Estimation of phospholipides in human blood. J. Biol. Chem., 1947, 169, 137.

24. Sinclair, R. G., The lecithin, cephalin, and sphingomyelin content of serum. I. As indicated by the choline-phosphorus and nitrogen-phosphorus ratios. J. Biol. Chem., 1948, 174, 343.

25. Folch, J., Personal communication.

26. Chaikoff, I. L., and Kaplan, A., The blood lipids in completely depancreatized dogs maintained with insulin. J. Biol. Chem., 1934, 106, 267.

27. Stueck, G. H., Rubin, S. H., Clarke, D. H., Graef, I., and Ralli, E. P., Studies on patients with cirrhosis of the liver. Plasma and liver lipid distribution and its relation to the pathology of the liver. Am. J. Med., 1948, 5, 188.

28. Entenman, E., Chaikoff, I. L., and Friedlander, H. D., The influence of ingested choline upon choline-containing and non-choline-containing phospholipids of the liver as measured by radioactive phosphorus. J. Biol. Chem., 1946, 162, 111. 